\title{
Gemcitabine-Vinorelbine Regimen
}

National Cancer Institute

\section{Source}

National Cancer Institute. Gemcitabine-Vinorelbine Regimen. NCI Thesaurus. Code C63412.

A regimen consisting of gemcitabine and vinorelbine used to treat advanced-stage nonsmall cell lung cancer. 